\title{
Antihypertensive effects of the methylene chloride leaf extract of Celtis durandii Engler (Ulmaceae) on rats
}

\author{
F. NTCHAPDA ${ }^{1^{*}}$, T. DIMO ${ }^{2}$ and A. T. ATCHADE ${ }^{3}$ \\ ${ }^{I}$ Department of Biological Science, Faculty of Science, University of Ngaoundéré, B P 454 Ngaoundéré- \\ Cameroon. \\ ${ }^{2}$ Department of Animal Biology and Physiology, Faculty of Science, University of Yaoundé - I, B P 812 \\ Yaoundé - Cameroon. \\ ${ }^{3}$ Department of Organic Chemistry, Faculty of Science, University of Yaoundé - I, B P 812 Yaoundé- \\ Cameroon. \\ ${ }^{*}$ Corresponding author, E-mail: ntchapda71@yahoo.fr, Tel: 0023722158484 / 0023777921869
}

\begin{abstract}
Celtis durandii (Ulmaceae), one of the plants used in traditional medicine to cure migraine, epilepsy, and high blood pressure, was administrated as antihypertensive in normotensive rats (NTR) and hypertensive saline rats (HSR). The antihypertensive effects of the methylene chloride extract of the plant were evaluated in NTR and HSR by the invasive method. Results indicated that $C$. durandii induce a decreased blood pressure after administration of the extract. This sudden decrease was followed by a slight increase, and then by an antihypertensive late activity of the extract that lasted for one hour. At a dose of $20 \mathrm{mg} / \mathrm{kg}$, the antihypertensive late activity of $C$. durandii extract was $42 \%$ in NTR and $65.21 \%$ in HSR. The urinary excretion of $\mathrm{Na}^{+}$ increased by $260 \%$ and $475 \%$ respectively in NTR and HSR at the dose of $300 \mathrm{mg} / \mathrm{kg}$ while that of $\mathrm{K}^{+}$ increased by $260 \%$ and $123 \%$ in the same animals at the same dose. The results suggest that $C$ durandii possesses an antihypertensive activity that could result from its diuretic effects. This activity could be explained by decrease of surrounding resistances.

(C) 2010 International Formulae Group. All rights reserved.
\end{abstract}

Keywords : Celtis durandii, Blood pressure, Hypotension, Diuretic, Rat .

\section{INTRODUCTION}

The over use in automedication of phytotherapeutic preparations is the main means to cure about $80 \%$ population who is unable to get access to manufactured drugs (Ojewole, 2006). High blood pressure represents the most frequent cardiovascular disease in the world (WHO, 1992). It is an important risk factor to development of other cardiovascular diseases and constitutes one of the main causes of mortality in the world
(Waeber and Brunner, 1994). Its prevalence in industrialized countries is $15 \%$ compared to $15-20 \%$ in underdeveloped ones (Ngu and Youmbissi, 1992). High blood pressure is a serious disease still with problematic care in our sub-region. It requires a daily medication all over the life of the patient that could be very expensive with manufactured drugs, thus not available to the population. Despite the wide therapeutic means available in modern medicine, patients are still dependent on 
phytotherapy. Each of the medicinal plants has several properties that traditional practitioners empirically exploit to cure diseases.

Celtis durandii Engler (Ulmaceae) is a medicinal plant of humid tropical zones used empirically in Cameroon by traditional healers in the treatment of different infections among which are: migraine, epilepsy, painful menses, cardio-vascular disorders, especially arterial hypertension, kidney disorders (Adjanohoun, 1996; Letouzey, 1968).

Phytochemical studies have revealed the presence of proteins, alkaloids and tannins in its leaves (Baranga, 1983). This work was carried out to evaluate the antihypertensive effects of the methylene chloride extract of $C$. durandii leaves on Wistar rats.

\section{MATERIALS AND METHODS \\ Experimental animals}

Experiments were conducted on Wistar rats of 3 to 4 months old and weighing 150$250 \mathrm{~g}$. They were raised in the animal house of the Faculty of Science, University of Yaoundé I in two groups.

- Normotensive rats (NTR) group with systolic blood pressure lower than or equal to $140 \mathrm{mmHg}$;

- Hypertensive saline rats (HSR) group with systolic blood pressure higher than 140 $\mathrm{mmHg}$.

The protocol used to induce the high blood pressure with salt in rats was described by Dimo et al. (2005). The Hypertensive saline rats (HSR) were obtained by imposing a hypersodic diet to Normotensive rats (NTR) for 9 weeks at a rate of $2 \mathrm{ml} / 100 \mathrm{~g}$ body weight of animal. Animal were regularly provided with water in a $1.2 \% \mathrm{NaCl}$ solution. The rats of the control lot received an equivalent volume of distilled water and had access to ordinary tap water.

\section{Plant material}

Fresh leaves of $C$. durandii were collected around Yaoundé in October. A voucher specimen $\mathrm{N}^{\circ}$ 6291/SRF CAM documenting the collection was identified at the National Herbarium, Yaoundé and is on deposit there. The leaves were sun-dried and ground into powder. Then, air dried powdered leaves of $C$. durandii ( $1 \mathrm{~kg}$ ) were macerated in $6 \mathrm{~L}$ of methylene chloride at room temperature for a week with occasional shaking, filtered, and concentrated to dryness on a rotary evaporator under reduced pressure to afford a deep green methylene chloride extract (300 g), with an extraction yield of $32 \%$ (Dimo et al., 2005). This extract (100 g) was dissolved in two drops of tween $80(1 \%)$ and the solution adjusted to $10 \mathrm{ml}$ with distilled water to obtain a stock solution of 10 $\mathrm{mg} / \mathrm{ml}$ (Ntchapda et al., 2009). Further dilution was made in physiological salt solution. The final tween concentration did not produce significant effect on contractile response. Phytochemical screening of the methylene chloride leaf extract of $C$. durandii was done using standard methods.

\section{Effect of $C$. durandii extract on arterial pressure}

The NTR and HSR were anesthetized by intraperitoneal administration of ethyl carbamate $(1.5 \mathrm{~g} / \mathrm{kg})$. The windpipe was intubated with a polyethylene tube $(3 \mathrm{~mm}$ diameter) in order to facilitate spontaneous respiration. The extract and reference substances were administrated through a catheter placed within the femoral vein. The maximal volume administered was $0.1 \mathrm{ml} / 100$ g body weight (Dimo et al., 2005). The arterial pressure was recorded by introduction of a catheter connected to a pressure transductor $(P A N L A B)$ in left carotid artery. The registering apparatus of blood pressure was a multispeed polygraph with four Harvard tracks. The $C$. durandii extracts were administrated $10 \mathrm{~min}$ after injection of $0.9 \%$ $\mathrm{NaCl}$ solution and their effects on the variation of the blood pressure were observed for 1 hour.

\section{Effect of $C$. durandii extract on diuresis in rat}

A preliminary test of selection was carried out by administration of $0.9 \% \mathrm{NaCl}$ 
solution to rats $(1 \mathrm{ml} / 100 \mathrm{~g}$ dry weight). The urinary volume was then evaluated after 4 hours. Animal able to excrete at least $40 \%$ of the administrated volume were selected while those who excreted less than $40 \%$ volume were excluded (Dimo et al., 2005). The NTR and HSR were individually placed in metallic cages for acclimatisation for 48 hours. Selected rats received by oral administration different doses $(225 \mathrm{mg} / \mathrm{kg}, 300 \mathrm{mg} / \mathrm{kg})$ of $C$. durandii and the urinary volume determined after 24 hours. The sodium and potassium in urine were quantified using a flame photometer of the type JENWAY, PFP7.

\section{Statistical analysis}

Data are expressed as mean \pm SEM $(n=$ 5), $n$ representing the number of rats used in each experiment. The One-way analysis of variance (ANOVA) of the "Mintab" program was used to determine the differences between treatments. A P value of $<0.05$ was considered statistically significant.

\section{RESULTS}

\section{Phytochemical composition}

Phytochemical screening of the methylene chloride leaf extract of $C$. durandii revealed the presence of flavonoids, phenols, sterols, alkaloids, ketones and triterpenes.

\section{Antihypertensive activity}

The effects of $C$. durandii on artery pressure were evaluated in NTR and HSR. In NTR anesthesized with ethyl carbamate, the intravenous administration of the methylene chloride extract of $C$. durandii showed a dosedependent decrease of the systolic, diastolic and average arterial pressure. The antihypertensive effects occurred after administration of the plant extract, and reached an optimal activity 45-60 min later. At $20 \mathrm{mg} / \mathrm{kg}$ extract, the initial AMP (artery mean pressure) of $105.29 \pm 2.74 \mathrm{mmHg}$ decreased to $82.06 \pm 4.30 \mathrm{mmHg}$, thus a reduction of $21 \%$. The pressure gradually increased to the initial values before a new decrease and stabilization at around 89.26 \pm $2.16 \mathrm{mmHg}$, for a $39 \%$ reduction of the AMP. C. durandii provoked an immediate and significant decrease in AMP at $20 \mathrm{mg} / \mathrm{kg}$ that passed from $116.93 \pm 5.90 \mathrm{mmHg}$ to $86.19 \pm$ $12.09 \mathrm{mmHg}$, thus a $37.75 \%$ reduction (Figure 1 ). The pressure increased up to the $20^{\text {th }} \mathrm{min}$, then decreased and was maintained at values lower than the initial pressure. The hypotensive maximal effect of $42 \%$ was observed 1 hour after administration of 20 $\mathrm{mg} / \mathrm{kg}$ dose of $C$. durandii. Atropine effect on the hypotensive activity of $C$. durandii was then assessed. Atropine was administrated 3 min before the methylene chloride extract (20 $\mathrm{mg} / \mathrm{kg}$ ) as shown in Figure 3. The pretreatment of animals with atropine (2 $\mathrm{mg} / \mathrm{kg}$ ) provoked a significant inhibition of the late hypotensive response induced by the extract.

In HSR the aqueous extract provoked a dose-dependent decrease in the arterial pressure 30 second after administration. The decrease of AMP changed from $16 \%$ at 20 $\mathrm{mg} / \mathrm{kg}$ to $36 \%$ at $20 \mathrm{mg} / \mathrm{kg}$. Whatever the concentration used, the arterial pressure remained lower than the initial value an hour after administration of the extract. The AMP initial of $152.23 \pm 3.35 \mathrm{mmHg}$ at a dose 20 $\mathrm{mg} / \mathrm{kg}$ was only $92.26 \pm 3.50 \mathrm{mmHg}$ after one hour, thus a significant decrease of $65.21 \%$ (Figure 2).

\section{Diuretic activity}

The effects of $C$. durandii on diuresis were assessed on NTR and HSR. The methylene chloride extract of $C$. durandii leaves $(225$ and $300 \mathrm{mg} / \mathrm{kg}$ ) provoked, 24 hours after administration, a significant $(\mathrm{P}<$ 0.05 ) and dose-dependent increase of the urinary volume. The urinary volume changed from $40.61 \pm 4.91 \mathrm{ml} / \mathrm{kg}$ in control to $55.32 \pm$ $4.43 \mathrm{ml} / \mathrm{kg}$ in NTR treated with $225 \mathrm{mg} / \mathrm{kg}$ of the extract, and $73.12 \pm 6.94 \mathrm{ml} / \mathrm{kg}$ in rats treated with $300 \mathrm{mg} / \mathrm{kg}$ extract (Table 1). In HSR, the urinary volume increased by respectively 36.36 and $97 \%$ at 225 and 300 $\mathrm{mg} / \mathrm{kg}$ (Table 2). The increased excretion of $\mathrm{Na}^{+}$was 260 and $475 \%$ respectively in NTR and HSR at the dose of $300 \mathrm{mg} / \mathrm{kg}$. The urinary excretion of $\mathrm{K}^{+}$increased by $160 \%$ in NTR administered the extract at the dose of $225 \mathrm{mg} / \mathrm{kg}$, while at $300 \mathrm{mg} / \mathrm{kg}$, the increase was $260 \%$. 


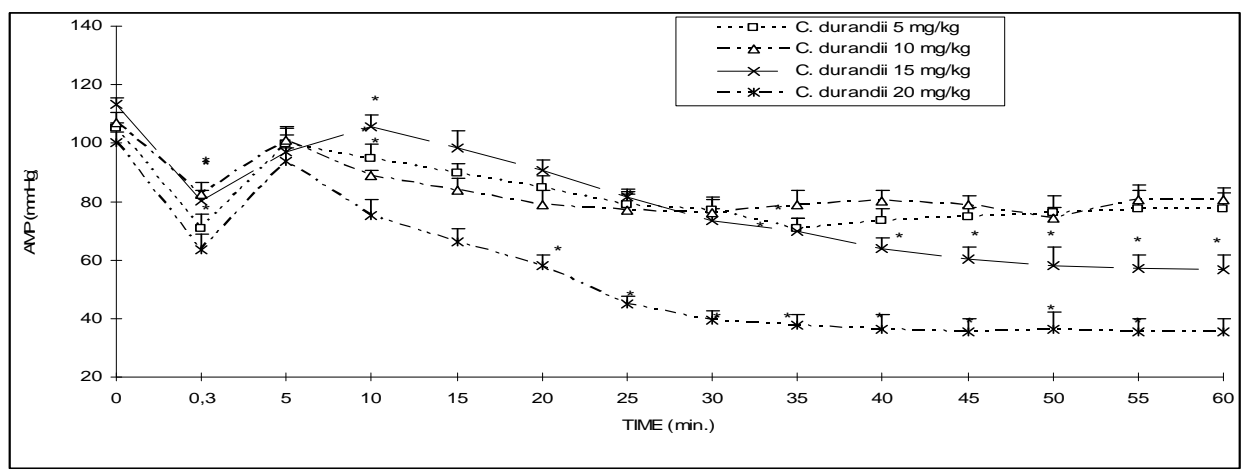

Figure 1: Effects of the methylene chloride extract of Celtis durandii on the arterial mean pressure in Normotensive rats.

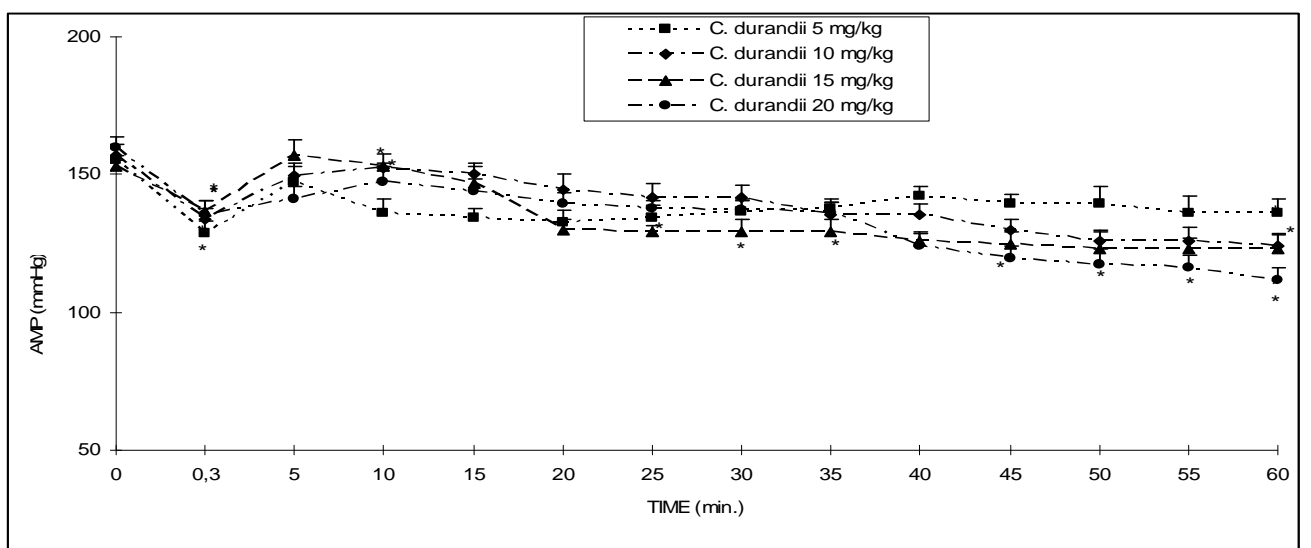

Figure 2: Effects of the methylene chloride extract of Celtis durandii on the arterial mean pressure in Hypertensive saline rats.

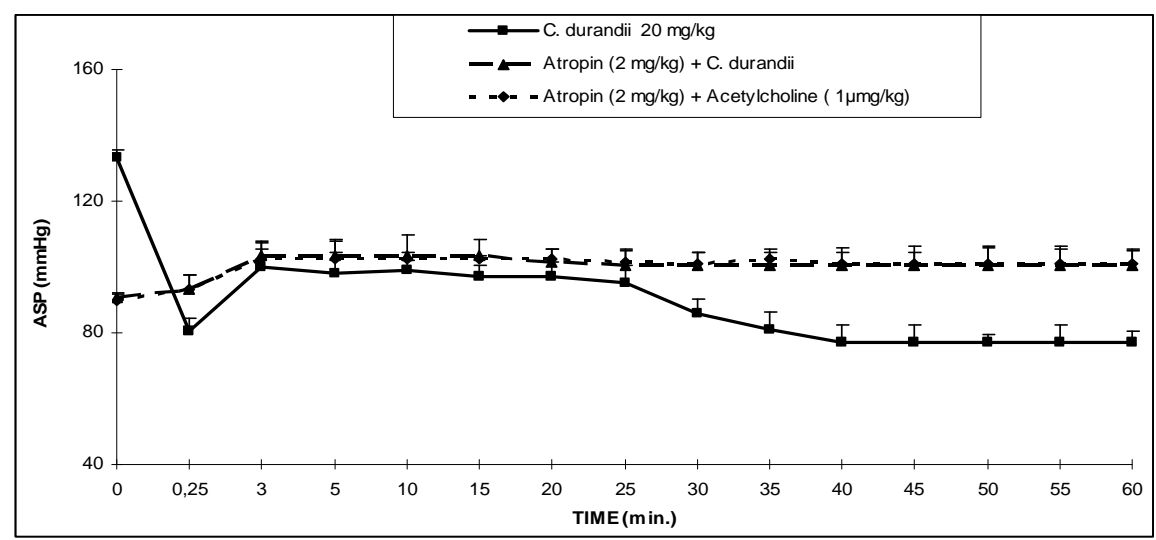

Figure 3: Effects of atropine on hypotensive activity of methylene chloride extract on arterial systolic pressure in Normotensive rats. 
Table 1: Effects of the methylene chloride extract of Celtis durandii on the urinary volume and excretion of $\mathrm{Na}^{+}, \mathrm{K}^{+}$in NTR.

\begin{tabular}{lcccc}
\hline Normotensive rats (NTR) & $\begin{array}{c}\text { Urinary } \\
\text { Volume } \\
\left(\mathbf{m L} / \mathbf{k g} / \mathbf{2 4}^{\mathbf{h}}\right)\end{array}$ & $\begin{array}{c}{\left[\mathbf{N a}^{+}\right]} \\
\left(\mathbf{m e ́ q} / \mathbf{k g} / \mathbf{2 4} \mathbf{4}^{\mathbf{h}}\right)\end{array}$ & $\begin{array}{c}{\left[\mathbf{K}^{+}\right]} \\
(\mathbf{m e ́} \mathbf{q} / \mathbf{k g} / \mathbf{2 4}\end{array}$ \\
\hline Distilled water & $10 \mathrm{ml} / \mathrm{kg}$ & $40,61 \pm 4,94$ & $4,95 \pm 1,10$ & $5,83 \pm 1,50$ \\
$\mathrm{CH}_{2} \mathrm{Cl}_{2}$ extract & $225 \mathrm{mg} / \mathrm{kg}$ & $55,32 \pm 4,43^{*}$ & $13,60 \pm 1,82^{*}$ & $13,66 \pm 0,57^{*}$ \\
& $300 \mathrm{mg} / \mathrm{kg}$ & $73,12 \pm 6,94^{*}$ & $23,46 \pm 2,15^{*}$ & $18,89 \pm 1,75^{*}$ \\
Furosemide & $2 \mathrm{mg} / \mathrm{kg}$ & $67,5018,14^{*}$ & $13,69 \pm 2,93^{*}$ & $9,44 \pm 2,46^{*}$ \\
A. hydrochlorothiazide & $14 \mathrm{mg} / \mathrm{kg}$ & $79,87 \pm 7,06^{*}$ & $23,63 \pm 4,88^{*}$ & $6,23 \pm 1,49$
\end{tabular}

Data are expressed as mean \pm SEM $(n=5), n$ representing the number of rats used in each experiment. $\mathrm{P}<0.05$ was considered to be statistically significant. $\mathrm{A}=$ Amiloride, $\mathrm{mé} q=$ milli-equivalent.

Table 2: Effects of the methylene chloride extract of Celtis durandii on the urinary volume and excretion of $\mathrm{Na}^{+}, \mathrm{K}^{+}$in HSR.

\begin{tabular}{|c|c|c|c|c|}
\hline \multicolumn{2}{|c|}{ Hypertensive saline rats (HSR) } & \multirow{2}{*}{$\begin{array}{c}\begin{array}{c}\text { Urinary } \\
\text { Volume } \\
\text { (mL/kg/24 }\end{array} \\
49,42 \pm 4,29\end{array}$} & \multirow{2}{*}{$\begin{array}{c}{\left[\mathbf{N a}^{+}\right]} \\
\left(\text {(méq/kg/24 }^{\mathbf{h}}\right) \\
33,37 \pm 1,03\end{array}$} & \multirow{2}{*}{$\begin{array}{c}{\left[\mathbf{K}^{+}\right]} \\
\left(\mathbf{m e ́ q} / \mathbf{k g} / \mathbf{2 4} \mathbf{4}^{\mathbf{h}}\right) \\
13,77 \pm 2,69\end{array}$} \\
\hline Distilled water & $10 \mathrm{ml} / \mathrm{kg}$ & & & \\
\hline $\mathrm{CH}_{2} \mathrm{Cl}_{2}$ extract & $225 \mathrm{mg} / \mathrm{kg}$ & $77,82 \pm 5,66^{*}$ & $60,70 \pm 4,80^{*}$ & $22,76 \pm 2,30 *$ \\
\hline & $300 \mathrm{mg} / \mathrm{kg}$ & $97,42 \pm 14,33 *$ & $119,63 \pm 18,85^{*}$ & $29,85 \pm 1,79 *$ \\
\hline Furosemide & $2 \mathrm{mg} / \mathrm{kg}$ & $91,12 \pm 9,81 *$ & $121,93 \pm 20,06^{*}$ & $15,91 \pm 2,42$ \\
\hline A. hydrochlorothiazide & $14 \mathrm{mg} / \mathrm{kg}$ & $93,17 \pm 8,91^{*}$ & $125,20 \pm 5,86^{*}$ & $8,07 \pm 1,91$ \\
\hline
\end{tabular}

In HSR, it was observed a decreased urinary excretion of $\mathrm{K}^{+}$by $69 \%$ at the dose of $225 \mathrm{mg} / \mathrm{kg}$ and a $123 \%$ increased urinary excretion of $\mathrm{K}^{+}$at $300 \mathrm{mg} / \mathrm{kg}$ of extract. Amiloride hydrochlorothiazide $(14 \mathrm{mg} / \mathrm{kg})$ provoked an increased excretion of the urinary volume and $\mathrm{Na}^{+}$, but did not significantly modify the urinary excretion of $\mathrm{K}^{+}$. Furosemide $(2 \mathrm{mg} / \mathrm{kg})$ provoked an increased excretion of the urinary volume and of $\mathrm{K}^{+}$and $\mathrm{Na}^{+}$in NTR and HSR.

\section{DISCUSSION}

The results indicate that the methylene chloride extract of $C$. durandii leaves provoked a dose-dependent decrease in the arterial pressure in both NTR and HSR. At 20 $\mathrm{mg} / \mathrm{kg}$ for example, the extract provoked an immediate decrease in AMP of $42 \%$ in NTR and $65.21 \%$ in HSR. This sudden drop in the pressure suggests an action of $C$. durandii on the efficacy of the cardiac pump. Such a decrease is followed by a transient increase, then by a further drop in the pressure which reaches an optimal activity within 45 to 55 min. The sudden decrease of the arterial pressure observed during intravenous administration resembles the action observed with acetylcholine.

The hypotensive activity of $C$. durandii (20 $\mathrm{mg} / \mathrm{kg}$ ) was comparable to that of acetylcholine $(1 \mu \mathrm{g} / \mathrm{kg})$ inhibited by atropine. The late antihypertensive activity might reflect the high affinity of the extract with its receptor and a slow dissociation of the decrease of peripheral resistances (Siok-Koon et al., 2009; Chan et al., 2006). The main factors contributing to the development of 
high blood pressure in HSR might be the great permeability of $\mathrm{Ca}^{++}$and the elevated intracellular concentration of $\mathrm{Ca}^{++}$in the smooth vascular fibrous muscle, that increase the vascular strength (Ntchapda et al., 2009; Ojewole, 2006; Asano et al., 1995). The methylene chloride extract of $C$. durandii induced, as well as furosemide and amiloride hydrochlorothiazide, a significant increase in the urinar excretion. In addition to its antidiuretic activity, furosemide $(2 \mathrm{mg} / \mathrm{kg}$ ) provoked an enhanced urinary excretion of $\mathrm{Na}^{+}$by $176.56 \%$ in NTR and $265.38 \%$ in HSR. The increment of $\mathrm{K}^{+}$excretion was $61.92 \%$ and $15.54 \%$ respectively in NTR and HSR. Amiloride hydrochlorothiazide, as the methylene chloride extract, increased the urinary excretion of $\mathrm{Na}^{+}$in HSR and has no effect on the excretion of $\mathrm{K}^{+}$that was increased only after administration of 300 $\mathrm{mg} / \mathrm{kg}$ of methylene chloride extract to HSR. It was reported that the abnormal increase in volume leads to high blood pressure (SiokKoon et al., 2009; Dimo et al., 1999). The antihypertensive activity of $C$. durandii might be explained by its diuretic properties (Dimo et al., 2005). The increased excretion of $\mathrm{Na}^{+}$ might reduce the glomerular filtration rate by enhancing the $\mathrm{Na}^{+}$charge available for the $\mathrm{Na}^{+}<==>\mathrm{K}^{+}$exchange and by stimulating, in addition, these exchanges with hyperaldosteronism that it provokes while reducing the blood mass. The increase of $\mathrm{Na}^{+}$ in macula densa inhibits the renine secretion, thus increasing the filtration rate of glomerular but the decrease in blood mass increases the secretion of renine (Bisognano et al., 2007; Waeber et al., 1992).

This study has demonstrated that the methylene chloride extract of $C$. durandii has an important therapeutic effect justifying its empirical and free utilization by population. This extract could play an important role in homeostasis of arterial pressure. The extract decreases the arterial pressure in NTR and HSR. It also provokes an enhancement of diuresis and natriuresis. The antihypertensive effects of $C$. durandii may result partly from its diuretic activity.

\section{REFERENCES}

Adjanohoun JE, Aboubakar N, Dramane K, Ebot ME, Ekpere JA, Enow Orock EG, Focho D, Gbile ZO, Kamanyi A, Kamsu KJ, Keita A, Mbenkum T, Mbi CN, Mbiele AL, Mbome H, Mubiru NK, Nancy WL, Nkongmeneck B, Satabu B, Sofowora A, Tamze V, Wirmum CK. 1996. Traditional medicine and pharmacopoeia: Contribution to ethnobotanical and floristic studies in Cameroon. Centre de Production de Manuels Scolaires : Porto Novo, Benin.

Asano M, Nomura Y, Ito K, Uyama Y, Imaizumi Y, Watanabe M. 1995. Increased of voltage-dependant $\mathrm{Ca}^{++}$ activated $\mathrm{K}^{+}$channels in resting state of femoral arteries from spontaneously hypertensive stage. J. Pharmacol., 275(1): 775-783.

Baranga D. 1983. Changes in chemical composition of food parts in the diet of colobus monkeys. J. Biochem. Ecolo$g y$, 64(2): 668-673.

Bisognano JD, Trent McLaughlin, Craig SR, Tang SSK. 2007. Calcium channel blockers, angiotensin receptor blockers, and angiotensin-converting enzyme inhibitors: Effectiveness in combination with diuretics or $\beta$-blockers for treating hypertension. Vascular Health and Risk Management, 3(5): 579-585.

Chan PN, Mao JC, Huang SH, Ning L, Wang ZJ, On T, Duan W and Zhu YZ. 2006. Analysis of cardioprotective effets using purified Salvia miltiorrhiza extract on isolated rat hearts. J. Pharmacol. Sci., 101: $245-249$.

Dimo T, Nguelefack BT, Kamtchouing P, Dongo E, Rakotonirina A, Rakotonirina SV. 1999. Effet hypotensif de l'extrait au methanol de Bidens pilosa Linn chez les rats hypertendus. C. R. Acad. Sci., 322 : 323-329.

Dimo T, Ntchapda F, De Théodore Atchade A, Kamtchouing P, Panjo Yewah M, Rakotonirina SV, Ngassam P. 2005. Effets hypotensifs de l'extrait au chlorure de méthylène/méthanol des feuilles de 
Celtis durandii Engler chez les rats hypertendus. Ethnopharmacologia, 36: 84-90.

Dimo T, Ntchapda F, Atchade AT, Yewah MP, Kamtchouing P, Ngassam P. 2005. Effects of methylene chloride/methanol leaf extract of Celtis durandii Engler (ulmaceae) on constriction of rat aorta. Pharmazie, 60(7): 548-550.

Eno AE, Ibokette UE, Ofem OE, Unoh FB, Nkanu E, Azah N, Ibu JO. 2004. The effects of a Nigerians species of viscum album (Mistletoe) extract on the blood pressure of normotensive and Docainduced hypertensive rats. Tropic. Cardiol., 14: 153-158.

Letouzey R. 1968. Ulmacées et Urticacées. Muséum National d'Histoire Naturelle, Laboratoire de phanérogamie: Paris.

Ngu BK, Youmbissi JT. 1992. Manuel d'Hypertension Artérielle. CUSS, Université de Yaoundé : Yaoundé.

Ntchapda F, Dimo T, Atchade AT, Mbongue Fandio YG. 2009. Effects of the aqueous leaf extract of Celtis durandii Engler (Ulmaceae) on constriction of rat aorta. Pharmacologyonline, 1(1): 424-431.
Ojewole JAO, Kamadyaapa DR, Musabayane CT. 2006. Some in vitro and in vivo cardiovascular effects of Hypoxis hemerocallidea Fisch \& CA Mey (Hypoxidaceae) corm (African potato) aqueous extract in experimental animal models. Cardiovascular Journal of South Africa, 17(4): 166-171.

Siok-Koon Yeo, Lay-Gaik Ooi, Ting-Jin Lim, Min-Tze Liong. 2009. Antihypertensive Properties of Plant-Based Prebiotics. Int. J. Mol. Sci., 10: 3517-3530.

Waeber B, Brunner H R. 1994. Hypertension artérielle modérée; les messages de L'étude TOMHS. Médecine et Hygiène, 52: 85-88.

Waeber B, Nussberger J, Brunner HR. 1992. Antihypertenseurs. Dans Pharmacologie des concepts fondamentaux aux applications thérapeutiques ( $2^{\mathrm{e}}$ edn). Ed. Frison-Roche: Paris.

WHO. 1992. Research guideline for evaluating the safety and efficacy of herbal medicines, prepared during the meeting of the working group of the safety and efficacy on herbal medicine, Manila, Philippines. 